DOI: https://doi.org/10.15276/hait.03.2021.5
UDC 004.942:621.3.078.4

\title{
Information supply of the power control system of the synchronous generator of the autonomous wind unit
}

\author{
Mykola Ya. Ostroverkhov ${ }^{1}$ \\ ORCID: https://orcid.org/0000-0002-7322-8052; n.ostroverkhov@hotmail.com \\ Vadim V. Chumack ${ }^{1)}$ \\ ORCID: https://orcid.org/0000-0001-8401-7931; chumack_kpi@ukr.net \\ Yevhen A. Monakhov ${ }^{1)}$ \\ ORCID: https://orcid.org/0000-0001-8408-8051; emonachov@ gmail.com \\ Bogdan I. Pryymak ${ }^{1)}$ \\ ORCID: https://orcid.org/0000-0001-7680-8565; bp-08@ukr.net \\ 1) National Technical University of Ukraine "Igor Sikorsky Kyiv Polytechnic Institute”, 37, Peremogy Ave. Kyiv, Ukraine
}

\begin{abstract}
This paper deals with information supply of automatic maximum power control system of synchronous hybrid excited generator for the autonomous wind unit. The power supply system based on an autonomous wind turbine consists of an electric generator, a battery charging controller, a battery pack and an inverter, which provides the required frequency and value of the consumer's supply voltage. Three phase permanent magnet synchronous generator that have high technical and economic indicators are most widely used as electric generator of autonomous wind turbines. The main disadvantage of these generators is the lack of effective methods of magnetic flux control, limiting the optimization of the energy balance of the wind turbine. The paper discusses the application of synchronous generator with hybrid excitation system that consists of permanent magnets and additional field excitation winding located on the stator. Mathematical model of a hybrid excited synchronous generator is presented. Also, an output maximum power control system in a case of wind speed change by varying field excitation current is developed. Control system is developed based on concept of reverse task of dynamics in combination with minimization of local functionals of instantaneous values of energies. In the basics of the control method is put an idea of the reversibility of the Lyapunov direct method for the stability analysis. Obtained control law provides the system stability in whole, which allows solving control tasks of interrelated objects via mathematical models of local loops. Control law also provides low sensitiveness to parametric disturbances and gives dynamic decomposition of interrelated non linear system that ensures its practical implementation. The study of the proposed power control system based on parameters of hybrid excited synchronous generator experimental sample has been carried out. The graphs of transient process of armature power, voltage and current in a case of wind speed change from 3 to $8 \mathrm{~m} / \mathrm{s}$ were obtained, as well as in a case of active resistance load change. The results of study showed high efficiency of power control of a wind turbine with hybrid excited synchronous generator.

Keywords: Information supply; automatic control; local functionality; hybrid excited synchronous generator; maximum power; wind turbine
\end{abstract}

For citation: Ostroverkhov M. Ya., Chumack V. V., Monakhov Y. A., Pryymak B. I. Information supply of the power control system of the synchronous generator of the autonomous wind unit. Herald of Advanced Information Technology. 2021; Vol. 4 No. 3: $255-267$. DOI: https://doi.org/10.15276/hait.03.2021.5

\section{INTRODUCTION}

Autonomous wind turbines are actively used for power supply of remote buildings and structures. A typical power supply system consists of a wind generator, a battery charge controller, a battery pack and an inverter, which provides the required value and frequency of the consumer's supply voltage.

Three phase permanent magnet synchronous generator (PMSG) that have high technical and economic indicators are most widely used as electric generator of autonomous wind turbines.

The main disadvantage of these generators is the lack of effective methods of magnetic flux control, limiting the optimization of the energy balance of the wind turbine.

During the operation of wind power turbine, the wind speed may change and generated energy power

(C) Ostroverkhov M., Chumack V., Monakhov Y.,

Pryymak B. I., 2021 will change respectively. The power of wind flow depends on the cube of the wind speed.

The mechanical characteristic of a wind turbine has a maximum power point. It is very important to solve the problem of selecting the maximum power of the turbine in conditions of wind speed change.

Accumulator battery as the electrical load of a synchronous generator of a wind turbine, is nonlinear. The value of the internal resistance of the battery depends on the degree of its charge. Highquality control of the coordinates of a synchronous generator is also associated with the solution of two more problems. The first problem is caused by parametric disturbances. During the generator operation its temperature changes and as a result, the values of the electrical resistances of the windings change. The initial values of the generator parameters can be determined inaccurately due to the errors of the corresponding calculation techniques. The second problem is caused by

This is an open access article under the CC BY license (http://creativecommons.org/licenses/by/3.0) 
coordinate disturbances, since a synchronous generator is described by an interrelated system of differential equations. The solution of these problems by classical methods of the theory of automatic control leads to the injection additional systems of identification, adaptation and/or compensation, which increases the bulkiness of the system as a whole.

\section{LITERATURE REVIEW}

To control the magnetic flux of a synchronous generator, synchronous generators with hybrid excitation (Hybrid Excitation Synchronous Generator (HESG)) are used. The excitation system consists of permanent magnets and a field excitation winding, which is located on a stationary stator [1]. The main magnetic flux is created by permanent magnets and about $20 \%$ in average - by the field excitation winding. The generator magnetic flux is controlled by changing the field winding current. Special attention should be paid to HESG designs with axial magnetic flux [2,3], which provide low synchronous rotation speeds. It allows to get a direct (gearless) coupling between the wind wheel and the generator. Such design is promising for use in autonomous wind power systems, since it allows expanding the control range and increasing the efficiency of converting wind energy into electrical energy.

Generator consists of following main parts (Fig. 1): 1 - stator core, made of electrical steel roll; 2 - copper one layer three phase winding; 3 permanent magnets located on rotor surface; 4 pole cores, which form and dimensions are identical to permanent magnets; 5 - rotor inductor that provides passing of the magnetic flux; 6 ferromagnetic hub, 7 - field excitation coil; 8 generator shaft. Such type of HESG is taken for research in this paper.

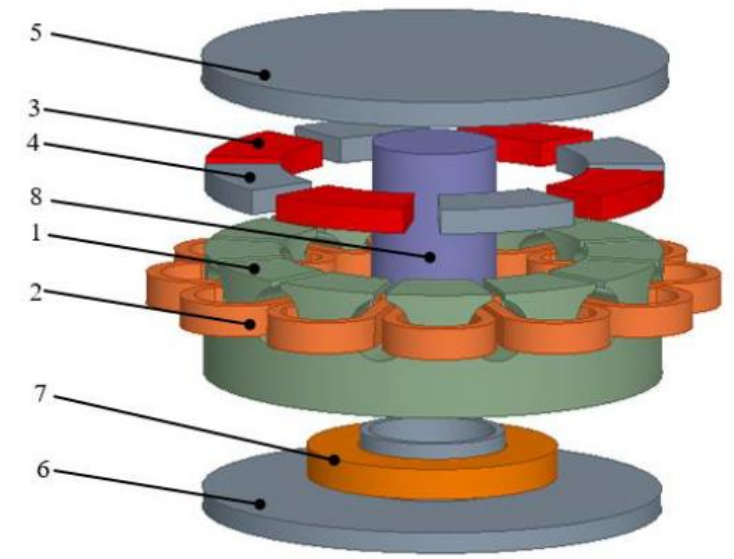

Fig. 1. Axial magnetic flux synchronous generator

Source: compiled by the authors
The wind speed is not constant. It causes a change in the rotation speed and mechanical power of the wind turbine. The graphs of the dependence of the output power of the turbine versus the wind speed have three areas of control of the wind generator, which are shown in Fig. 2 [4]. The paper studies the automatic control of a wind turbine while operating in the second zone at a variable rotation speed of a wind turbines shaft.

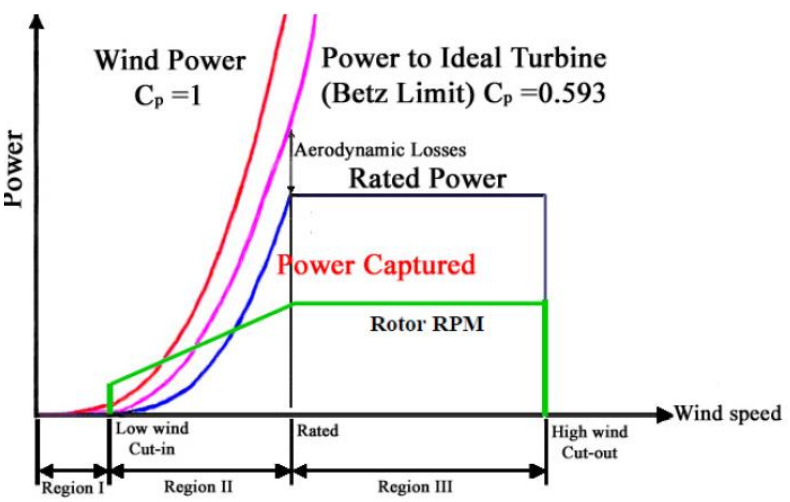

\section{Fig. 2. Turbine output power versus wind speed Source: [4]}

The system with power converter based on magnetic energy recovery (Magnetic Energy Recovery Switch (MERS)) [5, 6], [7] has been widely used for controlling the power flow of a permanent magnet synchronous generator (PMSG) during speed and load changes that is shown at Fig. 3.

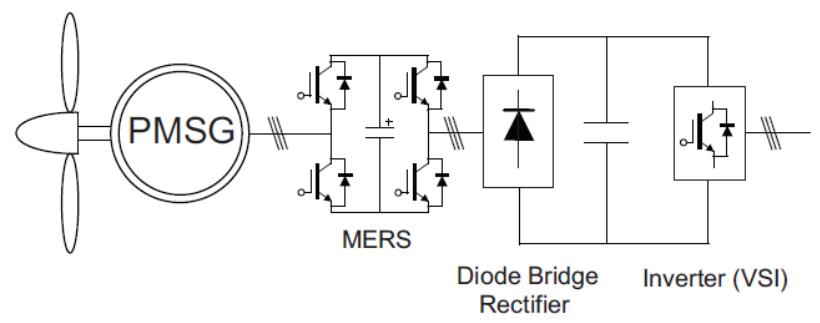

Fig. 3. Energy power conversion system of wind with MERS

Source: [6]

Phase MERS consists of four semiconductor switches, a capacitor and, according to its functional characteristics, there is a variable capacitor connected at the generator output (Fig. 4).

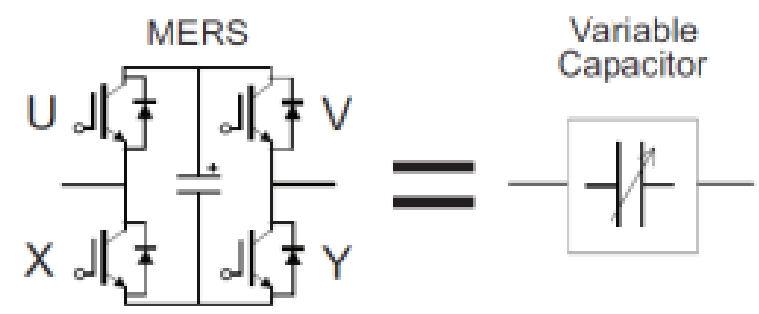

Fig. 4. MERS functional scheme Source: [6] 
This method of voltage and power control of a synchronous generator under conditions of wide variation of rotation speed has a few disadvantages: the MERS power is comparable to the generator power; the ability to control about the nominal speed of rotation with a small range of its change.

A synchronous electric machine, by its nature, like other types of $\mathrm{AC}$ machines, is an interconnected nonlinear control object, moreover, with the influence of eddy currents. Controlling a synchronous machine under such conditions requires compensation of the negative influence of these coordinate disturbances. The parameters determination of equivalent circuit of a synchronous machine via passport data may be accompanied with errors due to assumptions in the calculation method. During the operation of the machine, the electrical resistances of the windings change due to heating. As a result of these parametric disturbances, the calculated values of the parameters differ from the real ones, which lead to a deterioration of the specified control quality.

The problem of synthesizing control laws for the coordinates of a synchronous generator under conditions of parametric and coordinate disturbances can be solved by several methods of the theory of automatic control [8, 9], [10, 11], [12, 13], [14, 15], $[16,17],[18,19],[20,21]$ :

a) Relay control methods with variable structure ensure the operation of controllers in relay mode. This feature causes the appearance of specific sliding modes of operation. Sliding modes increase energy consumption for control and lead to increased wear of mechanisms, reduce the noise immunity of the system and may lead to unstable operation due to unaccounted dynamics. The reduction of this shortcoming is possible by interchanging the relay elements by linear links (elements) with saturation. As a result, smoothed methods with a variable structure are obtained. Systems based on them are close to relay ones in terms of dynamic characteristics; however, they develop limited control actions, which worsens control accuracy and robustness;

b) Methods with a large open-loop system gain have increased accuracy and robust stability with respect to parameter uncertainty and external lowfrequency influences. However, with large coefficients, instability of high-frequency unaccounted dynamics is possible, as well as the appearance of errors through high-frequency interference;

c) Combined control methods with uncertainty observers allow for a nonlinear non-stationary object to synthesize a linear stationary controller that provides the specified control quality indicators. In this method, the problems of external influences compensating and ensuring the specified quality indica- tors of transient processes are solved independently, which simplifies the synthesis. The disadvantage of this method is the complex conditions for ensuring the operability of the observer of uncertainty;

d) Adaptive control methods with real-time identification of parameters are mainly intended for linear systems. Their capabilities are limited with an increase of the number of parameters due to the need to fulfill the conditions for their identification, which are determined by the nature of the movement. It leads to raise of requirements for the nature of the movement of the system, which may not correspond to the technological process. In adaptive control methods besides a model, a model of the desired motion is set in the form of equations with initial conditions that are close to the initial conditions of the control object. Since the control system must track a given trajectory, the equations of motion are represented in the form of two components: the equations of the reference model and the equations of motion for this model. The equations of motion for complex objects are going to be non-linear and non-stationary. This circumstance complicates both the synthesis of control algorithms and the study of the stability of the trajectory;

e) The method of inverse problems of dynamics in combination with minimization of local functional of instantaneous values of energies is based on the idea of reversibility of the direct Lyapunov method for studying stability. The method allows finding a control law in which a closed loop has a predetermined Lyapunov function. It gives to system the property of stability in whole, which makes it possible to solve problems of control of interconnected objects according to mathematical models of local loops. One specific feature of optimization is finding not an absolute minimum of the quality functional, as in classical systems, but a certain minimum value, which ensures the dynamic error of the system admissible according to technical conditions. The obtained control laws ensure weak sensitivity to parametric disturbances, carry out a dynamic decomposition of an interconnected system and do not contain differentiating links, which ensures their practical implementation. The advantages of the method mentioned before determine its application in this paper.

\section{THE PURPOSE OF THE ARTICLE}

The purpose of the paper is developing information support for an automatic control system of the maximum power of hybrid excited synchronous generator of an autonomous wind turbine in a case of wind speed and load changes.

It is necessary to solve the following tasks to achieve the aim of the paper: 
a) To develop a functional diagram of the HESG maximum power automatic control system;

b) Combine HESG mathematical model;

c) To synthesize control laws for HESG coordinates based on the method of inverse problems of dynamics in combination with minimization of local functionals of instantaneous energy values;

d) To study the quality of regulation of the automatic control system of the maximum power of the synchronous generator of a wind turbine in a case of wind speed and load changes.

\section{MAIN PART. MATERIALS AND RESEARCH METHODS}

The development of information support for an automatic control system for the maximum power of a hybrid excited synchronous generator of an autonomous wind turbine is considered on the example of an experimental generator sample designed by the authors. A general view of the experimental HESG sample is shown in Fig. 5

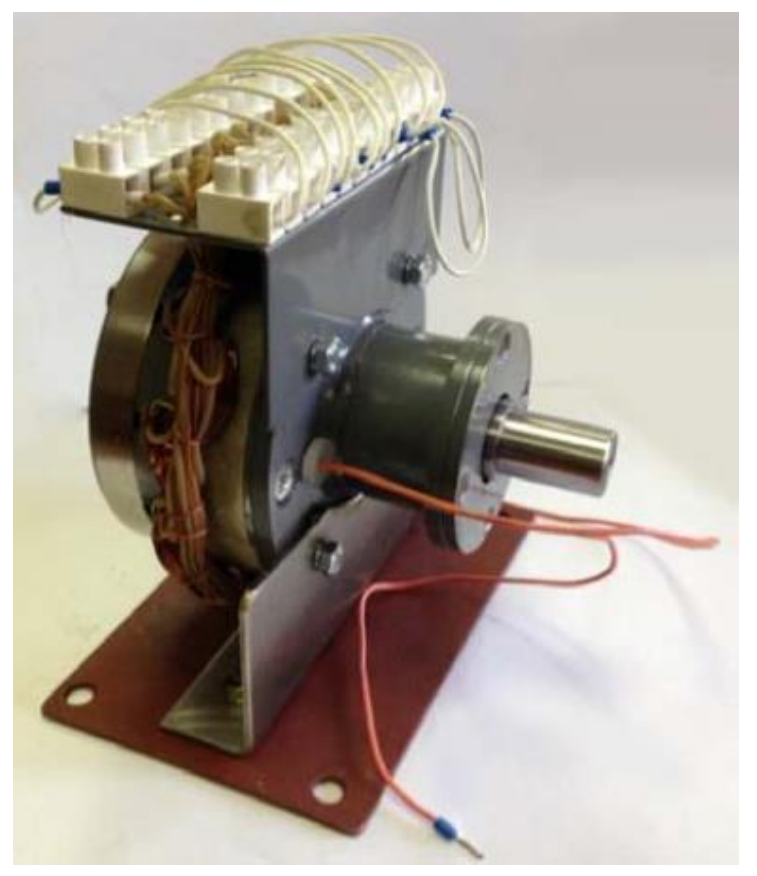

\section{Fig. 5. General view of HESG experimental sample \\ Source: compiled by the authors}

The main parameters of the experimental HESG are presented in Table. 1.

The output mechanical power versus wind speed of wind turbine for given experimental HESG in a case wind speed change from 3 to $8 \mathrm{~m} / \mathrm{s}$ are calculate and given at Fig. 6. The typical model of wind turbine in calculation has been used according to [22]. As seen from Fig. 6, for any value of rotation speed at the characteristics it can be observed an extremum point, that gives curve of maximum output power of turbine $P_{\max }$.
Table 1. Parameters of HESG experimental sample

\begin{tabular}{|c|c|}
\hline Parameters & Value \\
\hline Rated output power & $86 \mathrm{VA}$ \\
\hline Rated output voltage & $24 \mathrm{~V}$ \\
\hline Output current & $1.2 \mathrm{~A}$ \\
\hline Pole pairs & 4 \\
\hline Resistance of armature winding & $8.8 \mathrm{Ohm}$ \\
\hline Inductance of armature winding & $0.022 \mathrm{H}$ \\
\hline $\begin{array}{c}\text { Resistance of field excitation } \\
\text { winding }\end{array}$ & $8 \mathrm{Ohm}$ \\
\hline $\begin{array}{c}\text { Inductance of Field Excitation } \\
\text { winding }\end{array}$ & $0.017 \mathrm{H}$ \\
\hline Rated field excitation voltage & $8 \mathrm{~V}$ \\
\hline Rated field excitation current & $1 \mathrm{~A}$ \\
\hline Permanent magnet flux linkage & $0.16 \mathrm{~Wb}$ \\
\hline \multicolumn{2}{|c|}{ Source: compiled by the authors } \\
\hline
\end{tabular}

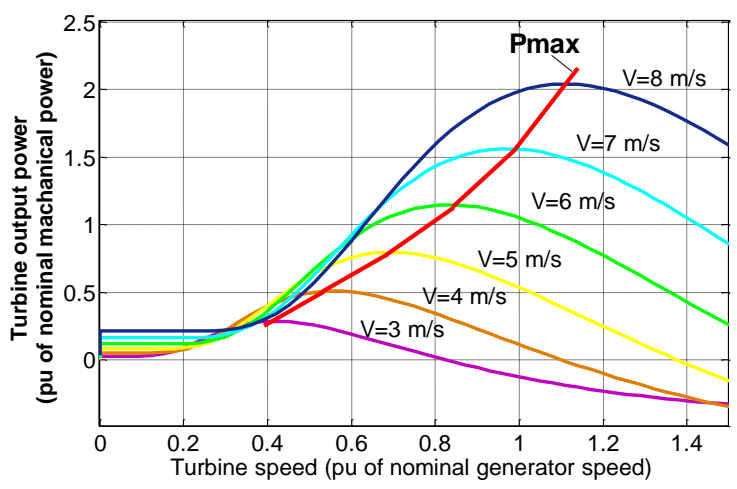

\section{Fig. 6. Mechanical power versus rotation speed of wind turbine for a given experimental HESG Source: compiled by the authors}

The task of automatic control system is selection of maximum power of wind turbine at the certain wind speed. Implementation of system is achieved by control of HESG field excitation current.

The functional diagram of the control system is shown in Fig. 7 where: PC - power generator controller; CC - controller of current field excitation; DCC - DC converter; CS - current field excitation sensor; PS - power sensor; $P_{\max }^{*}, P$ - referenced and measured value of mean generator power; $i_{f}^{*}, i_{f}-$ reference and measured value of field excitation current. The automatic control system has a cascade structure. It consists of an internal field excitation current control loop $i_{f}$ and an external control loop of the maximum electric generator power $P$. In the process of control, HESG loads the wind turbine 
with a torque $T$, ensuring operation at the extremum point on the mechanical characteristic according to Fig. 6.

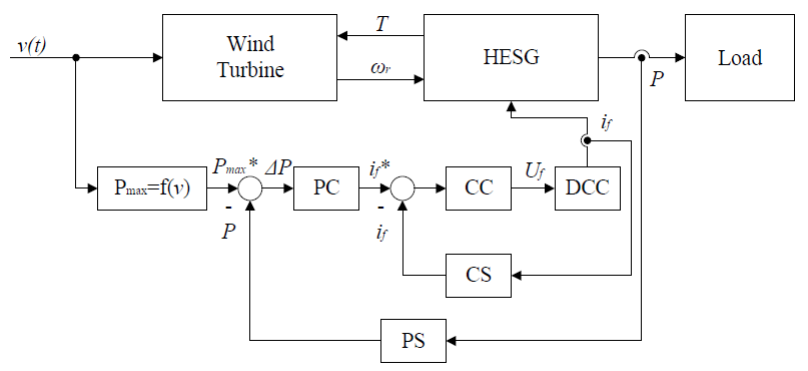

\section{Fig. 7. Functional control scheme of maximum power control of HESG of wind turbine Source: compiled by the authors}

Mathematical model of HESG in rotor coordinate $(\mathrm{d}-\mathrm{q})$, oriented by magnetic axis of rotor and is described by non-linear system of equations (1) [23, 24]

$$
\left\{\begin{array}{l}
\frac{d i_{d}}{d t}=\frac{1}{L_{s}}\left[u_{d}-R_{s} i_{d}+\omega L_{s} i_{q}-L_{m} \frac{d i_{f}}{d t}\right] \\
\frac{d i_{q}}{d t}=\frac{1}{L_{s}}\left[u_{q}-R_{s} i_{q}-\omega L_{s} i_{d}-\omega L_{m} i_{f}-\omega \psi_{0}\right] \\
\frac{d i_{f}}{d t}=\frac{1}{L_{f}}\left[u_{f}-R_{f} i_{f}-L_{m} \frac{d i_{d}}{d t}\right] \\
\frac{d \omega_{r}}{d t}=\frac{1}{J}\left[T_{W T}-T\right] \\
T=\frac{3}{2} Z_{p}\left[\psi_{0} i_{q} \pm L_{m} i_{q} i_{f}\right]
\end{array}\right.
$$

where: $i_{d}, i_{q}$ and $u_{d}, u_{q}-d$-axis and $q$-axis stator currents and voltages respectively; $i_{f}$ and $u_{f}$-current and voltage of field excitation; $\omega=Z_{p} \omega_{r}$ and $\omega_{r}$ - electrical and angular rotor speed; $Z_{p}$ - pole couple number; $J$ - inertia moment; $T, T_{W T}$ - electromagnetic torque and torque wind turbine; $\psi_{0}-$ permanent magnet flux linkage; $L_{s}, L_{f}, L_{m}$-stator, field excitation winding and mutual inductance; $R_{s}, R_{f}$ - resistances of stator and field excitation windings.

The control problem is solved by transformation of original system of equations (1) into the form (2) according to the decomposition method proposed in [25, 26], [27]. Coordinate disturbances $F_{1}, F_{2}, F_{3}$ are interpreted as uncertain, but have limited values $F_{1} \leq F_{1}^{0}$ , $F_{2} \leq F_{2}^{0}, F_{3} \leq F_{3}^{0}$. The level of control voltages is suf- ficient to compensate them $u_{d}>F_{1}^{0}, u_{q}>F_{2}^{0}, u_{f}>F_{3}^{0}$. Thus, the interconnected nonlinear system of the 4 th order is transformed into a system of 4 linear equations of the 1st order. As a result, the object control problem (1) is reduced to solution of four local control problems of linear subsystems (2).

$$
\left\{\begin{array}{l}
L_{s} \frac{d i_{d}}{d t}+R_{s} i_{d}=u_{d}+F_{1} \\
L_{s} \frac{d i_{q}}{d t}+R_{s} i_{q}=u_{q}+F_{2} ; \\
L_{f} \frac{d i_{f}}{d t}+R_{f} i_{f}=u_{f}+F_{3} ; \\
J \frac{d \omega_{r}}{d t}=\left[T_{W T}-T\right] ; \\
T=\frac{3}{2} Z_{p}\left[\psi_{0} i_{q} \pm L_{m} i_{q} i_{f}\right] \\
F_{1}=\omega L_{s} i_{q}-L_{m} \frac{d i_{f}}{d t} \\
F_{2}=-\omega L_{s} i_{d}-\omega L_{m} i_{f}-\omega \psi_{0} \\
F_{3}=-L_{m} \frac{d i_{d}}{d t} .
\end{array}\right.
$$

The desired quality of a closed control loop according to the concept of the inverse problem of dynamics $[19,20]$ is given by a differential equation in the following form

$$
\begin{aligned}
& \frac{d^{n} z}{d t^{n}}+. .+\gamma_{i} \frac{d^{i} z}{d t^{i}}+. .+\gamma_{0} z= \\
& =\beta_{m} \frac{d^{m} x^{*}}{d t^{m}}+. .+\beta_{j} \frac{d^{j} x^{*}}{d t^{j}}+. .+\beta_{0} x^{*} .
\end{aligned}
$$

Using the coefficients of the equation $\gamma_{\mathrm{i}}$ and $\beta_{\mathrm{j}}$ the desired character and duration of the transient process of the output coordinate $z$ is set while moving along a given trajectory $x^{*}$, where: $x^{*}$ - timedifferentiated function required number of times; $m<n$. The desired transfer function of the closed control loop, obtained on the basis of equation (3) for the case $n=3$ и $m=1$, has the form (where $p=d / d t$ - Laplace operator)

$$
W_{s}(p)=\frac{z(p)}{x^{*}(p)}=\frac{\beta_{1} p+\beta_{0}}{p^{3}+\gamma_{2} p^{2}+\gamma_{1} p+\gamma_{0}} .
$$

The corresponding transfer function open control loop is equal

$$
\begin{aligned}
& W_{r}(p)=\frac{W_{s}(p)}{1-W_{s}(p)}= \\
& =\frac{\beta_{1} p+\beta_{0}}{p^{3}+\gamma_{2} p^{2}+\left(\gamma_{1}-\beta_{1}\right) p+\left(\gamma_{0}-\beta_{0}\right)} .
\end{aligned}
$$


From equation (5) follows that to obtain a control system with first order astatism $v=1$ it is necessary to set the values of the coefficients $\beta_{0}=\gamma_{0}$, then

$$
W_{r}(p)=\frac{\beta_{1} p+\gamma_{0}}{p\left[p^{2}+\gamma_{2} p+\left(\gamma_{1}-\beta_{1}\right)\right]},
$$

and with a second order astatism $v=2$ it is necessary to set $\beta_{0}=\gamma_{0}$ и $\beta_{1}=\gamma_{1}$

$$
W_{r}(p)=\frac{\gamma_{1} p+\gamma_{0}}{p^{2}\left(p+\gamma_{2}\right)} .
$$

The given quality factor for the speed of system (6) defined by the expression $D_{\omega}^{z}=\gamma_{0} /\left(\gamma_{1}-\beta_{1}\right)$, and system acceleration quality factor (7) is equal $D_{\varepsilon}^{z}=\gamma_{0} / \gamma_{2}$. Order $n$ of equation (3) can be different for each closed control loop in accordance with the requirements for the quality of control and is usually equal to or by one higher than the order of the control object.

The structure and parameters of the equation of the desired quality of control (3) are set as follows, so that the disturbed motion would be asymptotically stable. According to the Hurwitz stability criterion for third order equation this condition is satisfied with the ratios of the parameters $\gamma_{0}>0 ; \gamma_{1}>0 ; \gamma_{2}>0$ and $\gamma_{1} \gamma_{2}>\gamma 0$, and for $2^{\text {nd }}$ and $1^{\text {st }}$ order equations - in a case of positive values of coefficients.

The relationship between the coefficients of equation (3) and the required control quality indicators, such as control time, type of transient process, overshoot, is easily established using the wellknown methods of the theory of automatic control, for example, root, frequency or standard polynomials, with subsequent refinement by modeling.

The development of the control law of the HESG field excitation current $i_{f}$ is carried out on the basis of the third equation of the system (2). As seen, the local control object is described by the first order equation, then an order of desired equation of the closed current (3) also taken equal to one $(n=1$; $m=0$ )

$$
\dot{z}+\gamma_{0 f} z=\gamma_{0 f} i_{f}^{*}
$$

that provides first order astatism $v=1$ and given quality factor by speed $D_{\omega}^{z}=\gamma_{0 f}$. Duration of monotonic current transient $t_{r} \approx 3 / \gamma_{0 f}$ is set by using the value of a single coefficient $\gamma_{0 f}$.

It is required to find such a control function of the field current regulator $u_{f}$, so that the quality of current control would be approach to the desired one, given by equation (8). The degree of approxi- mation of the real current control process to the desired one is estimated by the functional, which characterizes the inductance-normalized energy of the first derivative of the magnetic field in the form

$\dot{W}_{m}=L \frac{i^{2}}{2}$

$$
G\left(u_{f}\right)=\frac{1}{2}\left[\dot{z}(t)-\dot{i}_{f}\left(t, u_{f}\right)\right]^{2} .
$$

The control function finding $u_{f}=u_{f}\left(i_{f}\right)$ by classical methods of the theory of automatic control under the condition of reaching the absolute minimum of the functional

$$
\min _{u} G\left(u_{f}\right)=0 .
$$

Leads to the traditional control law of the compensation type, for the implementation of which precise information about the structure and parameters of the object is required. The deviation of the parameters from the calculated values leads to a deterioration in the quality of control.

This drawback can be eliminated in case of refusal to exactly fulfill condition (10), but only restrict by the requirement that the value of functional (9) belongs to some neighborhood of the extreme minimum, which provides a dynamic error admissible according to the technical conditions $\left|z(t)-i_{f}(t)\right| \leq \varepsilon$. So, the functional should be minimized according to the first-order gradient law

$$
\frac{d u_{f}(t)}{d t}=-\lambda_{f} \frac{d G\left(u_{f}\right)}{d u_{f}}
$$

where $\lambda_{f}>0-$ is constant.

Taking into account (2) and (8), the derivative of the functional is equal to

$$
\frac{d G\left(u_{f}\right)}{d u_{f}}=-\frac{1}{L_{f}}\left(\dot{z}-\dot{i}_{f}\right) .
$$

After substituting (12) into (11), the law of control of the excitation current can be found as

$$
\dot{u}_{f}(t)=k_{f}\left(\dot{z}-\dot{i}_{f}\right)
$$

where $k_{f}=\lambda_{f} / L_{f}=$ const - the gain coefficient of the field excitation current controller.

A necessary condition for the convergence of the process of minimizing the functional at $t \rightarrow \infty$

$$
\begin{aligned}
& \frac{d G\left(u_{f}\right)}{d t}<0 ; \\
& G\left(u_{f}\right) \rightarrow 0
\end{aligned}
$$

is met according to the rule of signs 


$$
\operatorname{sign}\left(k_{f}\right)=\operatorname{sign}\left(1 / L_{f}\right) .
$$

Variable $\dot{z}$ in control law (13) is the required (given) derivative of the excitation current, which is determined in real time from the equation of the desired quality (8) by closing the control system via excitation current feedback $z=i_{f}$

$$
\dot{z}=\gamma_{0 f}\left(i_{f}^{*}-i_{f}\right) \text {. }
$$

Finally, the control law of the field excitation current takes the form after the integration of both sides of equation (13), taking into account (16)

$$
\begin{aligned}
& u_{f}(t)=k_{f}\left(z-i_{f}\right) ; \\
& z=\gamma_{0 f} \int\left(i_{f}^{*}-i_{f}\right) d t .
\end{aligned}
$$

Based on (17) a block diagram of field excitation current controller (CC) of type $101(n=1 ; m=0$; $v=1)$ is designed and shown at Fig. 8.

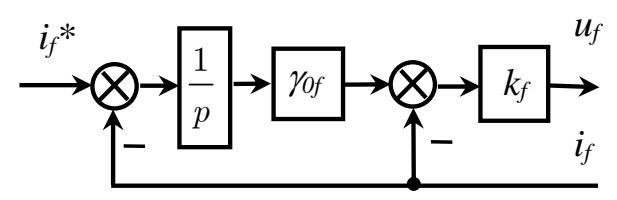

\section{Fig. 8. Field excitation current controller of generator of type 101 \\ Source: compiled by the authors}

As can be seen from the figure, the controller has an atypical structure and does not contain the parameters of the control object (2), which is typical for classical controllers. The controller contains only the parameter $\gamma_{0 f}$ of the desired control law (8), by which the required time of the monotone transient process is set.

An important task of the synthesis is study of the resulting control system stability. The equation of the closed loop of the excitation current, obtained after substituting the control law (13) into the third equation of the object (2), taking into account (16), has the form

$$
\begin{aligned}
& \ddot{i}_{f}+\left(R_{f} / L_{f}+k_{f} / L_{f}\right) \dot{i}_{f}+\left(k_{f} \gamma_{0 f} / L_{f}\right) i_{f}= \\
& =\left(k_{f} \gamma_{0 f} / L_{f}\right) i_{f}^{*} .
\end{aligned}
$$

Analysis shows that the closed-loop system (18) is stable even with an unlimited increase of the current controller gain coefficient $k_{f} \rightarrow \infty$, since according to the Hurwitz stability criterion, the coefficients of the equation are positive

$$
\left(R_{f} / L_{f}+k_{f} / L_{f}\right)>0 ; \quad\left(k_{f} \gamma_{0 f} / L_{f}\right)>0 .
$$

In a case of raise of gain coefficient of controller, the dynamic processes in the real circuit of the excitation current approach to the desired ones, given by equation (8), which is obvious after dividing all terms of equation (18) by the component $k_{f} / L_{f}$ at $k_{f} \longrightarrow \infty$

$$
\frac{L_{f}}{k_{f}} \ddot{i}_{f}+\left[\frac{R_{f}}{k_{f}}+1\right] \dot{i}_{f}+\gamma_{0 f} i_{f}=\gamma_{0 f} i_{f}^{*} .
$$

There is a small time constant $T_{\mu}$ in the field current control loop of power converter DCC, which was not taken into account during the control law synthesis. The estimation of the influence of this unaccounted inertia on the dynamic properties of the excitation current circuit is carried out using the closed-loop equation obtained similarly to (18)

$$
\begin{aligned}
& T_{\mu} \dddot{i}_{f}+\left(1+T_{\mu} R_{f} / L_{f}\right) \ddot{i}_{f}+ \\
& +\left(R_{1} / L_{f}+k_{f} / L_{f}\right) \dot{i}_{f}+ \\
& +\left(k_{f} \gamma_{0 f} / L_{f}\right) i_{f}=\left(k_{f} \gamma_{0 f} / L_{f}\right) i_{f}^{*} .
\end{aligned}
$$

According to the Hurwitz criterion for the stability of the current loop described by equation (20), the following condition is

$$
\begin{aligned}
& \left(1+T_{\mu} R_{f} / L_{f}\right)\left(T_{\mu} R_{f} / L_{f}+k_{f} / L_{f}\right)> \\
& >T_{\mu} k_{f} \gamma_{0 f} / L_{f},
\end{aligned}
$$

which turns into the following inequality as a result of the passage to the limit

$$
\gamma_{0 f}<1 / T_{\mu}+R_{f} / L_{f}
$$

Thus, the presence of a small constant time $T_{\mu}$ in the excitation current control loop limits the maximum permissible desired speed reaction of the current loop, which is set by the coefficient $\gamma_{0 f}$.

An important issue is also the determination of the properties of the field current loop at finite values of the controller gain coefficient $k_{f}$. According to the transfer function of the open current loop, obtained on the basis of (18) similarly to (5)

$$
W_{r}(p)=\frac{k_{f} \gamma_{0 f} / L_{f}}{p\left[p+\left(R_{f} / L_{f}+k_{f} / L_{f}\right)\right]}
$$

the current loop has a given first-order astatism $v=1$ and a quality factor by speed equal to

$$
D_{\omega}=\frac{k_{f} \gamma_{0 f} / L_{f}}{R_{f} / L_{f}+k_{f} / L_{f}}=\frac{\gamma_{0 f}}{R_{f} / k_{f}+1} .
$$

The condition for ensuring the permissible dynamic current error is a commensurate given and real quality factor $D_{\omega}^{z}=D_{\omega}$, which is fulfilled according to (24) with a large controller gain coefficient $k_{f}$. 
This disadvantage is eliminated if the control law is synthesized on the basis of the equation of the desired quality, the order of which is equal to $n=2$, which, in contrast to (8), is one order higher than the order of the equation of the local control object (the third equation of system (2))

$$
\ddot{z}+\gamma_{1 f} \dot{z}+\gamma_{0 f} z=\gamma_{0 f} i_{f}^{*} .
$$

Applying the above technique, the following law of control of the field excitation current is obtained

$$
\begin{aligned}
& u_{f}(t)=k_{f}\left(z-i_{f}\right) ; \\
& z=\int f_{0} d t ; \\
& f_{0}=\gamma_{0 f} \int\left(i_{f}^{*}-i_{f}\right) d t-\gamma_{1 f} i_{f} .
\end{aligned}
$$

According to equations (26), a block diagram of the field excitation current controller (CC) of type 201 is designed, shown in Fig. 9

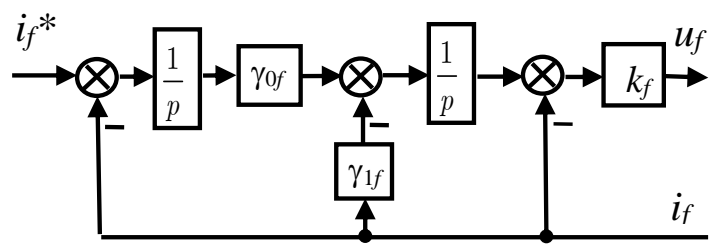

\section{Fig. 9. Field excitation current controller of generator of type 201 Source: compiled by the authors}

This controller also contains only the parameters of the desired control law $\gamma_{0 f}$ and $\gamma_{1 f}$, with the help of which the required type and time of the transient process, as well as the magnitude of the current overshoot, is established. The controller also does not contain the parameters of the control object, which is typical for classical laws.

It is seen from the transfer function of an open current loop for a given control law

$$
W_{r}(p)=\frac{k_{f} \gamma_{0 f} / L_{f}}{p\left[p^{2}+\left(R_{f} / L_{f}+k_{f} / L_{f}\right) p+k_{f} \gamma_{1 f} / L_{f}\right]},
$$

that the current loop has a given first-order astatism $v=1$ and quality factor by speed equal to the given

$$
D_{\omega}=D_{\omega}^{z}=\frac{\gamma_{0 f}}{\gamma_{1 f}} .
$$

It provides an acceptable dynamic current error at moderate controller gain coefficient $k_{f}$.

Development of the maximum HESG power control law $P$ is carried out on the basis of the desired closed loop equation of the first order $(n=1$; $m=0$ )

$$
\dot{z}+\gamma_{0 p} z=\gamma_{0 p} P_{\max }^{*},
$$

providing first-order astatism $v=1$ and a given quality factor in terms of speed $D_{\omega}^{z}=\gamma_{0 p}$. Duration of monotonic power transient process $t_{r} \approx 3 / \gamma_{0 p}$ is set by setting the value of the coefficient $\gamma_{0 p}$. After carrying out the synthesis of the control law, carried out similarly to the above synthesis for the field excitation current, the following equation of the power regulator is obtained

$$
\begin{aligned}
& i_{f}^{*}(t)=k_{p}(z-P) ; \\
& z=\gamma_{0 p} \int\left(P_{\max }^{*}-P\right) d t .
\end{aligned}
$$

Based on (30), a block diagram of the maximum power controller (PC) of type 101 is designed and shown in Fig. 10.

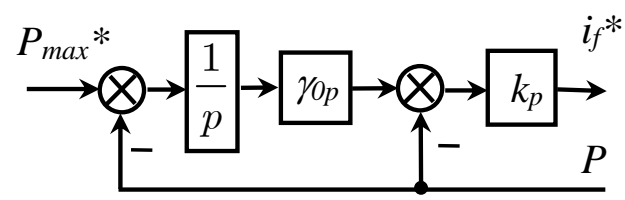

\section{Fig. 10. Maximum HESG power controller diagram of type 101 Source: compiled by the authors}

The power controller has an atypical structure and does not contain any parameters of the control object (2), which is typical for classical controllers. The controller contains only the parameter of the desired control law (29), with the help of which the required time of the monotonic transient process is set.

\section{RESEARCH RESULTS}

The study of the control quality of the developed system was carried out by simulation in the Matlab / Simulink environment with the parameters of the experimental HESG presented in table. 1. Field excitation current and maximum power of type 101 have the following parameters: $\gamma_{0 j}=1000$; $k_{f}=1000 ; \gamma_{0 p}=500 ; k_{p}=0.1$.

During the simulation, the wind speed varied from 3 to $8 \mathrm{~m} / \mathrm{s}$ for $10 \mathrm{~s}$, as shown in Fig. 11 .

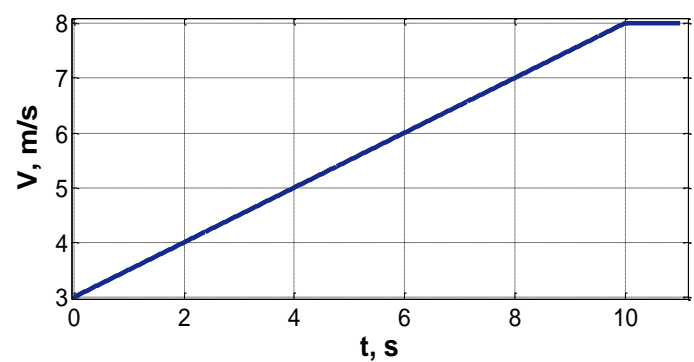

Fig. 11. Wind speed change graph Source: compiled by the authors

Wind speed changes causes the rotation speed change of HESG (Fig. 12). 


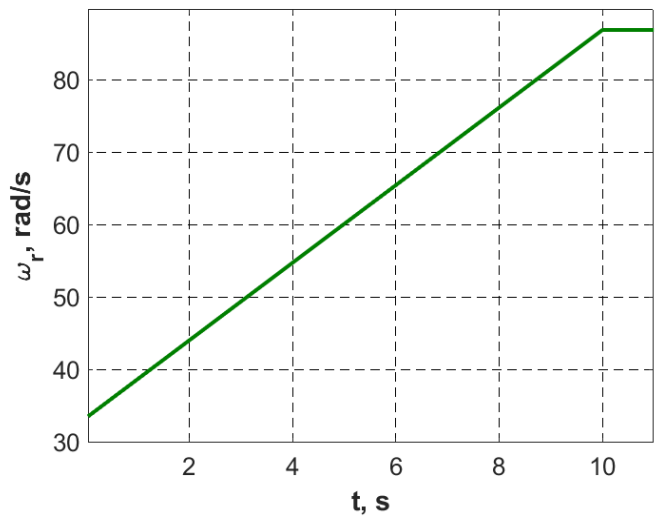

Fig. 12. HESG angular speed change graph Source: compiled by the authors

The control system calculates the maximum output power of the wind turbine depending on the wind speed (Fig. 13), which is the reference signal for the control loop of the output power of the electric generator.

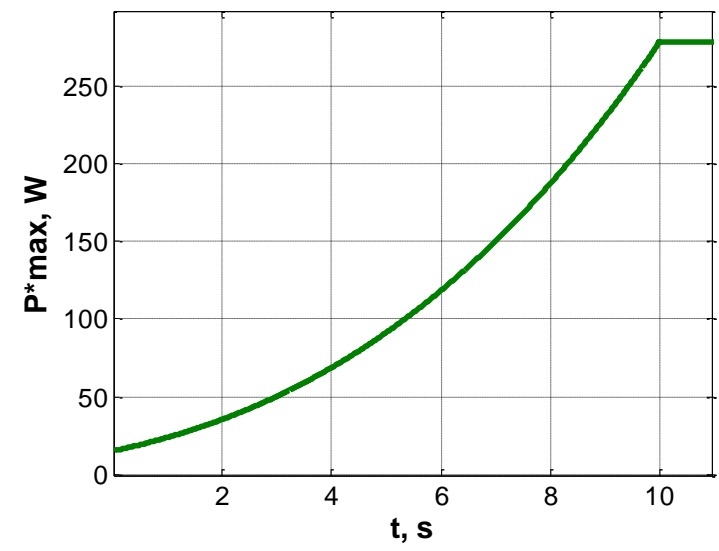

Fig. 13. Maximum output power of wind turbine Source: compiled by the authors

Thanks to the operation of the field excitation current and power controllers, HESG delivers the maximum electrical power to the load (Fig. 14).

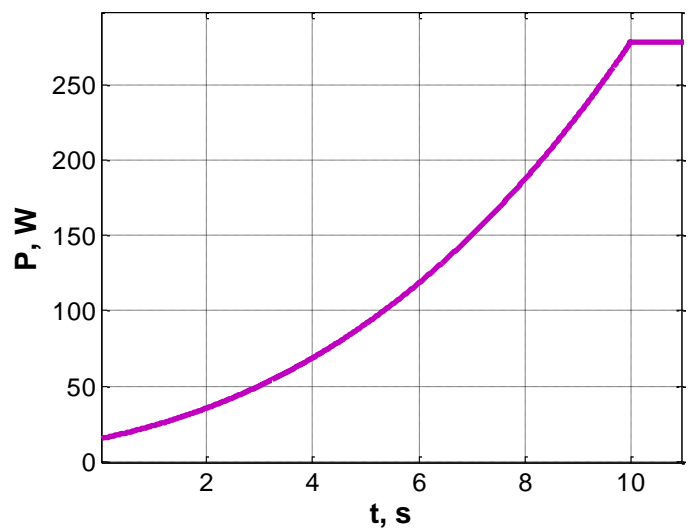

Fig. 14. HESG electric power output graph Source: compiled by the authors

The current and voltage graphs of field excitation winding during control process are shown in
Fig. 9 and fig. 10 respectively. Field excitation current and voltage increase whike wind speed raise and decrease with growth of load: $\mathrm{R}_{\text {load }}=36 \mathrm{Ohm}$; $30 \mathrm{Ohm} ; 24 \mathrm{Ohm}$.

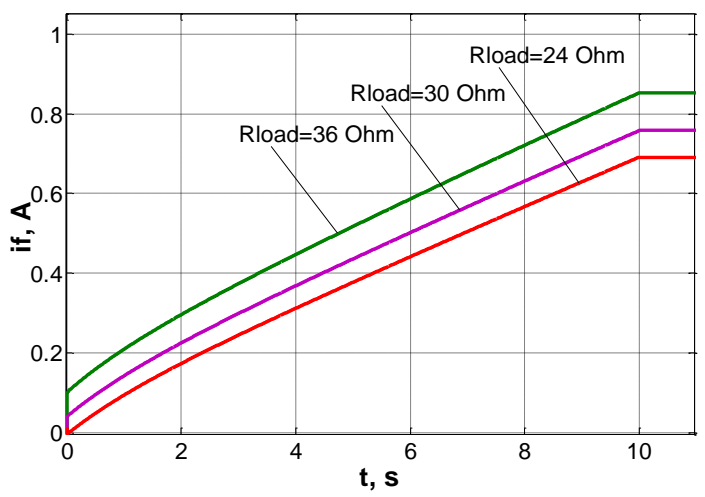

Fig. 15. HESG field excitation graphs Source: compiled by the authors

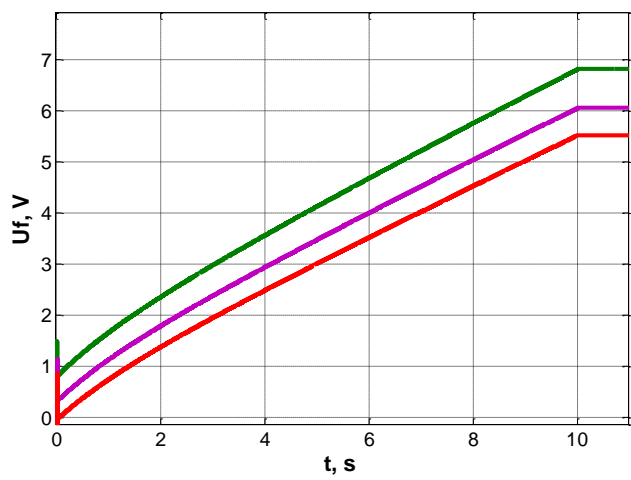

Fig. 16. HESG excitation voltage graphs Source: compiled by the authors

The armature current and voltage graphs of the HESG in a case of wind speed and load changes are shown in Fig. 17 and Fig. 18.

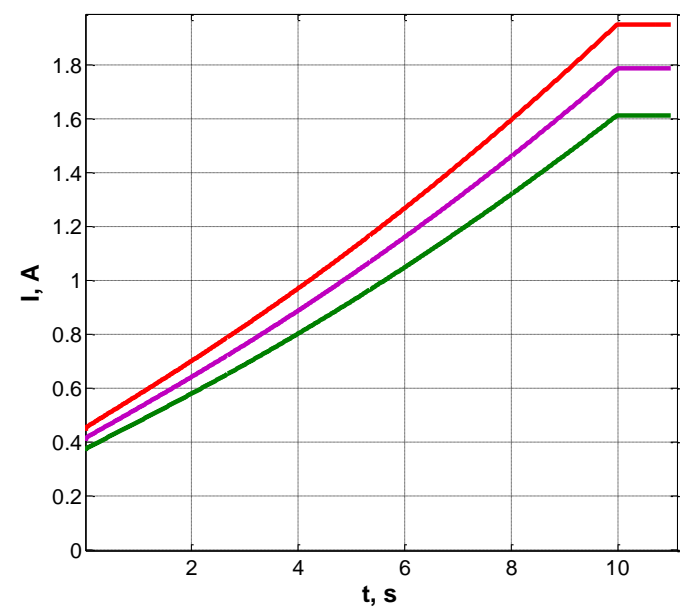

Fig. 17. HESG armature current graphs Source: compiled by the authors

When the wind speed changes from 3 to $8 \mathrm{~m} / \mathrm{s}$, the generator armature current raises from 0.38 to $1.6 \mathrm{~A}$ at a load of $36 \mathrm{Ohms}$ and from 0.46 to $1.98 \mathrm{~A}$ 
at $24 \mathrm{Ohms}$. Simultaneously, the generator stator voltage increases from 13.5 to $58 \mathrm{~V}$ at $36 \mathrm{Ohms}$ and from 11 to $47 \mathrm{~V}$ at $24 \mathrm{Ohms}$.

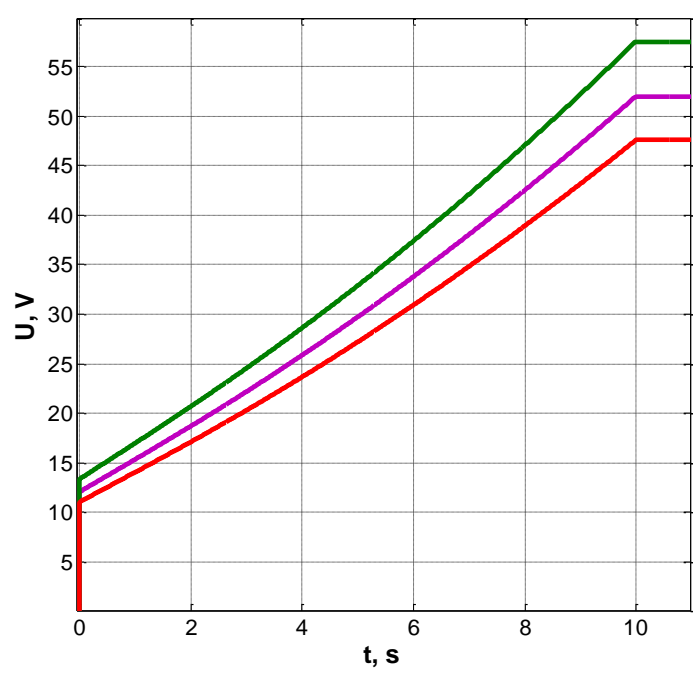

Fig. 18. HESG armature voltage graphs Source: compiled by the authors

An important issue is the study of the quality of transient processes in a squall wind and a sudden load change. In Fig. 19 it is shown a graph of the excitation current and in Fig. 20 graph of the maximum output power with an increase in the wind speed by sudden jump from 3 to $8 \mathrm{~m} / \mathrm{s}$.

The field excitation current and maximum power graphs are characterized by monotonic (without overshoot) transient processes during the time determined by the parameters of the controllers $\gamma_{0 f}$ and $\gamma_{0 p}$.

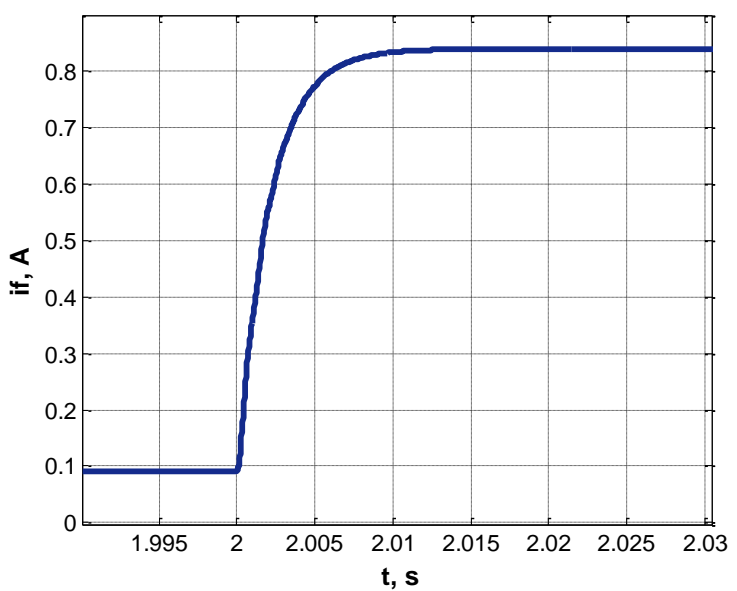

Fig. 19. Field excitation current transient process graph in a case of wind speed change Source: compiled by the authors

Fig. 21 shows excitation current graph, and Fig. 22 - maximum output power graph changes when the sudden jump occurs: the electrical resistance of the load changes from 36 to $24 \mathrm{Ohms}$ at a wind speed of $6 \mathrm{~m} / \mathrm{s}$. After the transient process finished, the maximum power assumes the previous value of $117 \mathrm{~W}$, and the excitation current decreases from 0.58 to $0.43 \mathrm{~A}$.

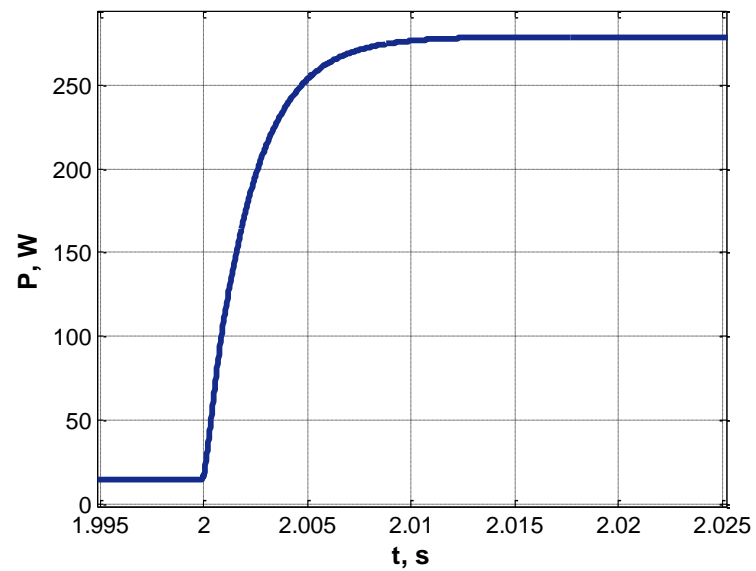

Fig. 20. HESG output electric power transient process graph in a case of wind speed change Source: compiled by the authors

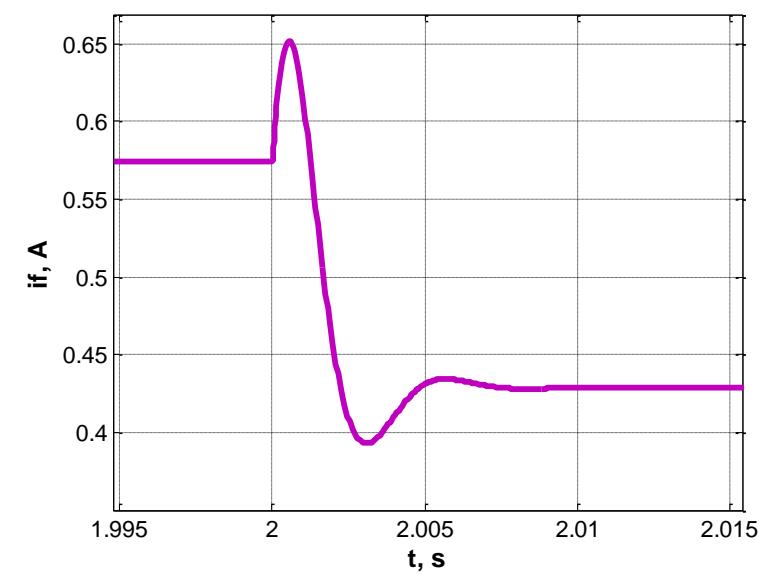

Fig. 21. Excitation current transient process graph in a case of load change Source: compiled by the authors

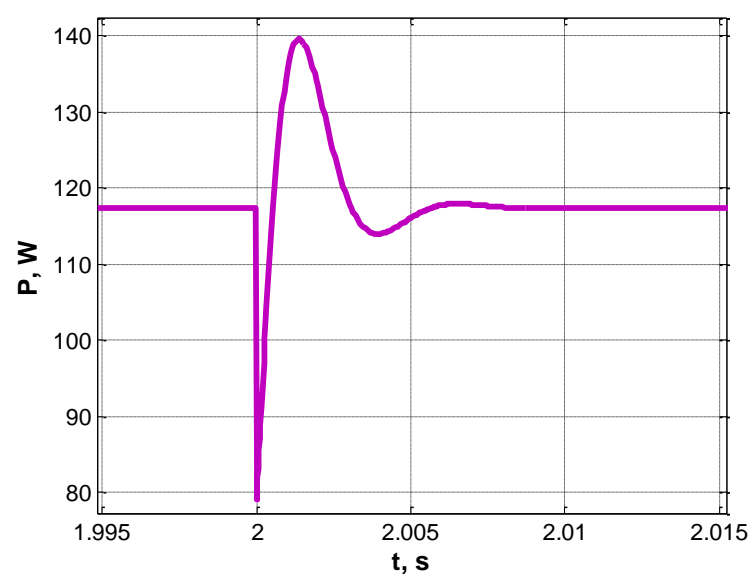

Fig. 22. Maximum output power transient process graph in a case of load change Source: compiled by the authors 


\section{CONCLUSIONS}

1. The application of hybrid excited synchronous generator in autonomous wind turbines allows getting maximum power from the wind turbine at different values of wind speed and generator load changes.

2. The HESG power control is carried out by changing the excitation current of additional field winding. The control system consists of internal excitation current control loop and external electric power control loop.
3 . The high quality of power and excitation current control is provided by original informational support, which is developed based on minimization of local functional of instantaneous values of electromagnetic energy. Control laws ensure robustness to parametric and coordinate disturbances and simplicity of controller implementation.

4. The study of control process of autonomous wind turbine on the example of experimental HESG sample approved high quality of maximum power control in a case of wind speed change from 3 to 8 $\mathrm{m} / \mathrm{s}$ and load change by $50 \%$.

\section{REFERENCES}

1. Xinghe, Fu \& Jibin, Zou. "Design and Analysis of a Novel Hybrid Excitation Synchronous Generator".3rd IEEE Conference on Industrial Electronics and Applications. 2008. p. 2074-2077. DOI: https://doi.org/10.1109/ICIEA.2008.4582885.

2. Ostroverkhov, M., Chumack, V. \& Monakhov, E. "Axial Flux Permanent Magnet Controlled Generator". IEEE 3rd International Conference on Intelligent Energy and Power Systems (IEPS). 2018. p. $353-$ 357. DOI: https://doi.org/10.1109/IEPS.2018.8559505.

3. Ostroverkhov, M., Chumack, V. \& Monakhov, E. "Ouput Voltage Stabilization Process Simulation in Generator with Hybrid Excitation at Variable Drive Speed". IEEE 2nd Ukraine Conference on Electrical and Computer Engineering (UKRCON). Lviv: Ukraine. 2019. p. 310-313. DOI: https://doi.org/10.1109/UKRCON.2019.8879781.

4. Chuang, N. "Robust $\mathrm{H}^{\infty}$ control of variable-speed wind turbines in partial load". Australasian Universities Power Engineering Conference (AUPEC). 2014. p. 1-6. DOI: https://doi.org/10.1109/ AUPEC.2014.6966563.

5. Wiik, J. A., Widjaya, F. D., Isobe, T., Kitahara T. \& Shimada, R. "Series Connected Power Flow Control using Magnetic Energy Recovery Switch (MERS)". Power Conversion Conference - Nagoya. 2007. p. 983-990. DOI: https://doi.org/10.1109/PCCON.2007.373086.

6. Kawaguchi, T., Sakazaki, T., Isobe T. \& Shimada, R. "Wind Turbine Generation System with Simple Rectifier Using MERS in Current Link Topology Wind Farm". 15th International Power Electronics and Motion Control Conference (EPE/PEMC). 2012. p. LS7c.2-1-LS7c.2-6. DOI: https://doi.org/10.1109/EPEPEMC.2012.6397511.

7. Wiik, J. A. et al. "Control Design and Experimental Verification of a Series Compensated $50 \mathrm{~kW}$ Permanent Magnet Wind Power Generator". IEEE Power Electronics Specialists Conference. 2008. p. 45254531. DOI: https://doi.org/10.1109/PESC.2008.4592677.

8. Biletskyi, Yu. O., Shchur, I. Z. \& Kuzyk, R.-I. V. "Passivity-Based Control System for Stand-Alone Hybrid Electrogenerating Complex". Applied Aspects of Information Technology. Publ. Nauka i Tekhnika. Odessa: Ukraine. 2021; Vol. 4 No. 2: 140-152. DOI: https://doi.org/10.15276/aait.02.2021.2.

9. Shchur, I., Rusek, A., Makarchuk, O. \& Lis, M. "The simulation Model of a Synchronous Machine with Permanent Magnets that Takes into Account Magnetic Saturation”. Przeglad Elektrotechniczny (Electrical Review). 2013; No. 4: 102-105.

10. Kuznetsov, B. I., Nikitina, T. B. \& Bovdui, I. V. "Multiobjective Synthesis of Two Degree of Freedom Nonlinear Robust Control by Discrete Continuous Plant". Tekhnichna Elektrodynamika. Kyiv: Ukraine. 2020; No. 5: 10-14. DOI: https://doi.org/10.15407/techned2020.05.010.

11. Kuznetsov, B., Bovdui I. \& Nikitina, T. "Nonlinear Robust Control Parametric Synthesis by Moving Plants with Elastic Elements". IEEE 6th International Conference on Methods and Systems of Navigation and Motion Control (MSNMC). 2020. p. 56-59. DOI: https://doi.org/10.1109/MSNMC50359.2020.9255656.

12. Pryymak, B., Moreno-Eguilaz, J. M. \& Peracaula, J. "Neural Network Flux Optimization Using a Model of Losses in Induction Motor Drives". In 8th international conference on modelling and simulation $f$ electric machines, converters and systems. 2006; Vol. 2 No. 12: 650-662. DOI: https://doi.org/10.1109/CIEP.2006.312164.

13. Tolochko, O. I., Kaluhin, D. V, Palis, Stefan \& Oshurko, S. V. "Field Weakening Control for Induction Motors Based on Copper and Iron Losses Minimization". Applied Aspects of Information Technolo- 
gy. Publ. Nauka $i \quad$ Tekhnika. Odessa: Ukraine. 2020; $\quad$ Vol.3 $\quad$ No.2: 44-57. DOI: https://doi.org/10.15276/aait.02.2020.3.

14. Tolochko, O., Kaluhin, D. \& Danylov, D. "Speed Vector Control of Induction Motor with Copper and Iron Losses Minimization". IEEE 2nd Ukraine Conference on Electrical and Computer Engineering UkrCon. Lviv: Ukraine. July 2-6, 2019. p. 408-413. DOI: https://doi.org/10.1109/UKRCON.

15. Nazarova, O. Osadchyy V. \& Brylystyi, V. "Research on the Influence of the Position of the Electric Vehicles Mass Center on Their Characteristics". IEEE Problems of Automated Electrodrive. Theory and Practice (PAEP). 2020. p. 1-4. DOI: https://doi.org/10.1109/PAEP49887.2020.9240824.

16. Nazarova, O. Osadchyy V. \& Shulzhenko, S. "Accuracy Improving of the Two-Speed Elevator Positioning by the Identification of Loading Degree". IEEE International Conference on Modern Electrical and Energy Systems (MEES). 2019. p. 50-53. DOI: https://doi.org/10.1109/MEES.2019.8896414.

17. Utkin. V. I. "Sliding Modes in Optimization and Control Problems" (in Russian). Publ. Nauka. Moscow: Russian Federation. 1981.

18. Potapenko, E. M. "Comparative Evaluation of Robust Control Systems with Different Types of Observers". Theory and control systems (in Russian). 1995; No. 1: 109-117.

19. Krut'ko, P. D. "Robustly Stable Structures of Control Systems of High Dynamic Precision. Algorithms and Dynamics of Control of Model Objects". Journal of Computer and Systems Sciences International (in Russian). 2005; Vol. 2: 120-140.

20. Ostroverkhov, M. Y. \& Buryk, M. P. "Speed Control System of Synchronous Motor Drives with Field Weakening using the Concept of Inverse Problems of Dynamics". IEEE 7th International Conference on Energy Smart Systems (ESS). 2020. p. 310-314. DOI: https://doi.org/10.1109/ESS50319.2020.9160008.

21. Ostroverkhov, N. \& Buryk, N. "Control System with Field Weakening of Synchronous Motor Drive". IEEE Problems of Automated Electrodrive. Theory and Practice (PAEP). 2020. p. 1-5. DOI: https://doi.org/10.1109/PAEP49887.2020.9240903.

22. Siegfried Heier. "Grid Integration of Wind Energy Conversion Systems". John Wiley \& Sons Ltd. 1998.

23. Ostroverkhov, M. Chumack, V. \& Monakhov, Y. "Robust Control of Hybrid Excited Synchronous Machine". IEEE 7th International Conference on Energy Smart Systems (ESS). 2020. p. 295-300. DOI: https://doi.org/10.1109/ESS50319.2020.9160058.

24. Mbayed, Rita. "Contribution to the Control of the Hybrid Excitation Synchronous Machine for Embedded Applications". Université de Cergy Pontoise. 2012.

25. Chernous'ko, F. L., Anan'evskij, I. M. \& Reshmin, S. A. "Methods of control nonlinear mechanical systems" (in Russian). Publ. Fizmatlit. Moscow: Russian Federation. 2006.

26. Ostroverkhov, M. \& Buryk, M."Control of Permanent Magnet Synchronous Motor under Conditions of Parametric Uncertainty". IEEE International Conference on Modern Electrical and Energy Systems (MEES). Kremenchuk: Ukraine. 2019. p. 98-101. DOI: https://doi.org/10.1109/MEES.2019.8896635.

27. Ostroverkhov, M. \& Buryk, M. "Vector Control of Field Regulated Reluctance Motor". IEEE 2nd Ukraine Conference on Electrical and Computer Engineering (UKRCON). Lviv: Ukraine. 2019. p. 486-490. DOI: https://doi.org/10.1109/UKRCON.2019.8879902.

Conflicts of Interest: the authors declare no conflict of interest

Received 08.12.2020

Received after revision 30.02 .2021

Accepted 16.03.2021

DOI: https://doi.org/10.15276/hait.03.2021.5

УДК 004.942:621.3.078.4

\section{ІНФОРМАЦЙНЕ ЗАБЕЗПЕЧЕННЯ СИСТЕМИ КЕРУВАННЯ МАКСИМАЛЬНОЮ ПОТУЖНІСТЮ СИНХРОННОГО ГЕНЕРАТОРА АВТОНОМНОЇ ВІТРОВОЇ УСТАНОВКИ}

Микола Якович Островерхов ${ }^{1)}$

ORCID: https://orcid.org/0000-0002-7322-8052; n.ostroverkhov@ @otmail.com

Вадим Володимирович Чумак ${ }^{1)}$ ORCID: https://orcid.org/0000-0001-8401-79314; chumack_kpi@ukr.net

Свген Андрійович Монахов)

ORCID: https://orcid.org/0000-0001-8408-8051; emonachov@gmail.com 


\title{
Богдан Іванович Приймак ${ }^{1}$ \\ ORCID: https://orcid.org/0000-0001-7680-85654; bp-08@ukr.net \\ 1) Національний технічний університет України «Київський політехнічний інститут імені Ігоря Сікорського», пр. Перемоги, 37, Київ, Україна
}

\begin{abstract}
АНОТАЦІЯ
У статті розроблено інформаційне забезпечення системи автоматичного керування максимальною потужністю синхронного генератора 3 гібридним збудженням автономної вітроустановки. Система електропостачання на основі автономної вітроустановки складається з електричного генератора, контролера заряду акумуляторних батарей, блока акумуляторних батарей та інвертора, за допомогою якого забезпечується необхідне значення і частота живлячої напруги споживача. В якості електричних генераторів автономних вітроустановок найбільшого поширення набули трифазні синхронні генератори 3 постійними магнітами, які мають високі техніко-економічні показники. Основним недоліком цих генераторів $є$ відсутність ефективних методів керування магнітним потоком, що обмежує оптимізацію енергетичного балансу вітроустановки. У статті запропоновано застосування синхронного генератора із гібридною системою збудження, яка складається із постійних магнітів та додаткової електричної обмотки збудження, розташованої на статорі. Представлена математична модель синхронного генератора із гібридним збудженням та розроблена система керування максимальною вихідною потужністю при зміні швидкості вітру шляхом регулювання струму збудження. Система керування розроблена на основі концепції зворотних задач динаміки в поєднанні з мінімізацією локальних функціоналів миттєвих значень енергій. В основу методу керування покладена ідея зворотності прямого методу Ляпунова $з$ дослідження стійкості. Отриманий закон керування надає системі властивість стійкості в цілому, що дозволяє вирішувати завдання керування взаємопов'язаним об'єктом за математичними моделями локальних контурів. Закон керування забезпечує також слабку чутливість до параметричних збурень об'єкта та здійснює динамічну декомпозицію взаємозалежної нелінійної системи, що зумовлює його практичну реалізацію. Проведено дослідження запропонованої системи керування потужністю на основі параметрів експериментального зразка синхронного генератора із гібридним збудженням. Отримано графіки перехідних процесів потужності, напруги та струму статора, напруги та струму збудження при зміні швидкості вітру від 3 до 8 м/с, а також при зміні активного електричного опору навантаження. Результати дослідження показали високу ефективність керування потужністю вітроустановки із синхронним генератором із гібридним збудженням.
\end{abstract}

Ключові слова: Інформаційне забезпечення, автоматичне керування; локальний функціонал; синхронний генератор 3 гібридним збудженням; максимальна потужність; вітроустановка

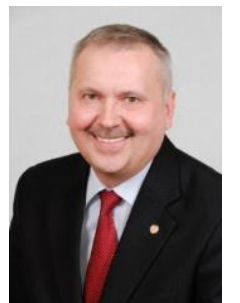

\section{ABOUT THE AUTHORS}

Mykola Yakovych Ostroverkhov, Dr. Sci. (Eng) (2013), PhD (Eng) (1991), Professor, Head of the Theoretical Electrical Engineering Department. National Technical University of Ukraine "Igor Sikorsky Kyiv Polytechnic Institute"37, Peremogy Ave. Kyiv, Ukraine

ORCID: https://orcid.org/0000-0002-7322-8052; n.ostroverkhov@ hotmail.com

Research field: Methods of control of interconnected electromechanical systems in the conditions of uncertainty of mathematical model of object; electromechanical automatic control systems with contactless actuators

Микола Якович Островерхов, доктор технічних наук (2013), кандидат технічних наук (1991), професор, завідувач кафедри Теоретичної електротехніки. Національний технічний університет України «Київський політехнічний інститут імені Ігоря Сікорського», пр. Перемоги, 37. Київ, Україна

Vadim Volodymyrovych Chumack, PhD (Eng) (1992), Associate Professor, Head of the Department Electromechanics, National Technical University of Ukraine "Igor Sikorsky Kyiv Polytechnic Institute"37, Peremogy Av. Kyiv, Ukraine ORCID: https://orcid.org/0000-0001-8401-7931; chumack_kpi@ukr.net Research field: Diagnostics and certification of electrical machines; special electrical machines

Вадим Володимирович Чумак, кандидат технічних наук (1992), доцент, завідувач кафедри Електромеханіки. Національний технічний університет України «Київський політехнічний інститут імені Ігоря Сікорського», пр. Перемоги, 37. Київ, Україна

Yevhen Andriovich Monakhov, PhD (Eng) (2019), Senior Lecturer at Department of Electromechanics, National Technical University of Ukraine "Igor Sikorsky Kyiv Polytechnic Institute"37, Peremogy Av., Kyiv, Ukraine

ORCID: https://orcid.org/0000-0001-8408-8051; emonachov@gmail.com

Research field: Permanent magnet machines; special electrical machines; power convertors.

Свген Андрійович Монахов, кандидат технічних наук (2019), старший викладач кафедри Електромеханіки, Національний технічний університет України «Київський політехнічний інститут імені Ігоря Сікорського», пр. Перемоги, 37, Київ, Україна

Bogdan Ivanovych Pryymak, PhD (Eng) (1996), Associate Professor of the Department Automation of Electromechanical Systems and the Electrical Drives, National Technical University of Ukraine "Igor Sikorsky Kyiv Polytechnic Institute", 37, Peremogy Ave., Kyiv, Ukraine

ORCID: https://orcid.org/0000-0001-7680-8565; bp-08@ukr.net

Research field: Synthesis of the Laws of Energy Efficient Control of Asynchronous Machines; Nonlinear Intelligent Control of High Quality Electromechanical Systems; Optimization of Electromechanical Systems Using Neural Networks and Genetic Algorithms.

Богдан Іванович Приймак, кандидат технічних наук (1996), доцент кафедри автоматизації Електромеханічних систем та електроприводу, Національний технічний університет України «Київський політехнічний інститут імені Ігоря Сікорського», пр. Перемоги, 37, Київ, Україна 